\title{
充放電電流と電圧のラプラス変換による電池インピーダンスの測定
}

\author{
学生員 中山 正人* 学生員 福田 健一* \\ 非会員 大森 吉剛* 学生員 若原 健二* \\ 正 員 荒木 拓人* 正 員 恩田 和夫*
}

\section{Battery Impedance Measurement by Laplace Transformation of Charge or Discharge Current/Voltage}

\begin{abstract}
Masato Nakayama*, Student Member, Kenichi Fukuda*, Student Member, Yoshitake Ohmori*, Non-member, Kenji Wakahara*, Student Member, Takuto Araki*, Member, Kazuo Onda*, Member
\end{abstract}

\begin{abstract}
Impedance spectroscopy of $Z(\omega)$ is often used in the electrochemical field to analyze electrode reactions and to calculate transient responses. Our previous study measured the overpotential resistance for our thermal behavior model to calculate the temperature rise of Nickel/metal-hydride battery or Lithium-ion battery during charge and discharge cycles. However, the $Z(\omega)$ measured by AC impedance meter did not agreed with the ones induced by charge/discharge characteristics. Therefore, we focus on the impedance measurement method by Takano et al, who obtained $Z(\omega)$ for Lithium-ion battery at wide frequency region by the Laplace transformation of both signals of the voltage-step input and its current response. We have extended this method to the Laplace transformation of current-step or current-pulse input signal and its voltage response signal to get $Z(\omega)$ for any charge/discharge current of Nickel/metal-hydride battery or Lithium-ion battery. We can get almost the same $Z(\omega)$ by the three different methods, and the measured $Z(\omega)$ does not depend on both charge/discharge current and the state of charge or the charge input. Moreover, $Z(\omega)$ including Warlbulg impedance at low frequencies gets near the overpotential resistance that can estimate well the battery temperature rise in our battery thermal behavior model.
\end{abstract}

キーワード : 複素インピーダンス解析, ラプラス変換, リチウムイオン電池, ニッケル水素電池

Keywords: complex impedance analysis, laplace transformation, lithium-ion battery, nickel metal/hydride battery

\section{1. はじめに}

近年のユビキタスネットワークや，環境負荷の少ない省 エネルギー機器を普及させようとする社会にあって，二次 電池は重要なキーデバイスで，携帯用機器からハイブリッ ド自動車まで広い分野で電源として活躍し，現在でも更な る発展が望まれている(1)。我々はこれまでニッケル水素や リチウムイオン電池を中心に, 電池の大型化や高出力化に おいて課題となる発熱挙動について研究してきた ${ }^{(2)(3)}$ 。電 池の主な発熱因子は，エントロピー変化や水素吸蔵による 吸発熱と, 副反応や電池過電圧による発熱である。特に急 速充放電時には, 電流の二乗に比例して過電圧発熱が大き くなるので, 過電圧抵抗を正確に推定する必要がある (2)(3)。 それを推定する際, 直流電流で測定した各種過電圧抵抗と,

\footnotetext{
*豊橋技術科学大学 電気. 電子工学系

干 441-8580 豊橋市天伯町雲雀ケ丘 1-1

Electrical and Electronic Eng., Toyohashi University of Technology

1-1, Hibarigaoka, Tenpaku-cho, Toyohashi 441-8580
}

交流インピーダンス計による複素インピーダンス $Z(\omega)(\omega$ は角周波数）の比較が難しいことが分かった。つまり，低 周波域での $Z(\omega)$ は活物質の拡散による Warburg インピー

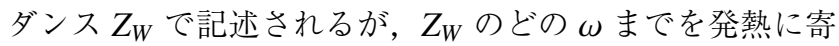
与する過電圧抵抗とすれば良いかが問題となる。複素イン ピーダンス解析は電気化学の分野では, 電極反応 ${ }^{(4)}$ や過渡 特性 ${ }^{(5)}$ などを解析する際良く使われるので, 両者が簡単に 比較できることが望ましい。ところで, 充放電電流を流し た二次電池の $Z(\omega)$ を交流インピーダンス計で計ろうとす ると, 電池の充電状態 (SOC) が刻々変わり, それに従い $Z(\omega)$ も変わるので正確に測定できない。

そこで, 交流インピーダンス計以外に充放電時の $Z(\omega)$ を 計る方法として, 我々は高野らのラプラス変換法 ${ }^{(6)}$ に着目 した。これは, 電圧ステップ入力に対する電流応答を測定 し, それぞれをラプラス変換し, その逆伝達関数から周波数 に対する $Z(\omega)$ を求める方法である。この電圧ステップ法 では充放電電流や SOC を規定することが難しいので, 我々 はこれを発展させ, 電流ステップや電流パルス入力に対す 
る電圧応答をラプラス変換し, $Z(\omega)$ を求める方法を考案し た。また，この方法で実際にニッケル水素やリチウムイオ ン電池の $Z(\omega)$ を測定し, 高野らの方法による結果と比較し た。更に，我々の方法で測定した $Z(\omega)$ から電池の等価回 路を作成し, 二次電池の発熱挙動を良く説明できた既報 (2)(3) の各種過電圧抵抗と比較し，その差を考察した。

\section{2. ラプラス変換による $Z(\omega)$ の測定法 ${ }^{(6)}$}

無負荷状態にある電池（ $t \leqq 0$ で $i=0, v=$ 一定）に印加 する電圧ステップ $v(t)$ に対する電流応答 $i(t)$ のそれぞれの ラプラス変換を $V(s), I(s)$ とすると, 逆伝達関数 $H(s)$ は, 次式で示される。

$$
H(s)=\frac{V(s)}{I(s)}=\frac{\int_{0}^{\infty} v(t) e^{-s t} d t}{\int_{0}^{\infty} i(t) e^{-s t} d t}
$$

$$
s=\alpha+j \omega
$$

ここで， $\alpha$ は実数の後述する収束変数， $\omega$ は角周波数であ り, $v(t)$ と $i(t)$ の間に線形関係を仮定している。

一方, 複素インピーダンス $Z(\omega)$ はフーリエ変換を用い, $t \leqq 0$ に拝いて $v(t)=0, i(t)=0$ なら，次式で示される。

$$
Z(\omega)=\frac{V(\omega)}{I(\omega)}=\frac{\int_{-\infty}^{\infty} v(t) e^{-j \omega t} d t}{\int_{-\infty}^{\infty} i(t) e^{-j \omega t} d t}=\frac{\int_{0}^{\infty} v(t) e^{-j \omega t} d t}{\int_{0}^{\infty} i(t) e^{-j \omega t} d t}
$$

このフーリエ積分は, $t \geqq 0$ で入力される電圧ステップに 対しては周期性が無いので収束しない。しかし，(1) 式の ラプラス積分は $\alpha$ が大きければ収束する。 $v(t)$ と $i(t)$ のラ プラス変換 $(1)$ 式は，それぞれを $v(t) e^{(-\alpha t)}$ と $i(t) e^{(-\alpha t)}$ とし たフーリエ変換 (3) 式であるとも言える。 $\alpha$ が大き過ぎる と, 長時間に渡って変化する $v(t)$ と $i(t)$ の情報を, $e^{(-\alpha t)}$ に よるマスキングで失ってしまう。 $\alpha$ が解析期間で適切であ れば，有限時間の積分が無限時間のラプラス積分の良い近 似となる。

このように，ラプラス逆伝達関数 $H(s)$ が，パラメータ $\alpha$ を用いた $\omega$ の関数として与えられるとき， $Z(\omega)$ は $\alpha \ll \omega$ に㧍けるテーラー展開より，(4) 式のように近似される。

$$
\begin{aligned}
Z(\omega) & \cong H(s)+\frac{\partial H(s)}{\partial s}(-\alpha) \\
& =H(\alpha+j \omega)+\frac{\partial H(\alpha+j \omega)}{\partial j \omega}(-\alpha) .
\end{aligned}
$$

実際のデー夕処理では，有限期間に抒ける有限デー夕は 高速フーリエ変換（FFT）アルゴリズムを用い，離散化さ れたラプラス変換により記録・解析される。 $\mathrm{T}$ を解析期間, $\mathrm{N}$ をサンプル数とすれば, $2 \pi / \mathrm{T}$ から $\mathrm{N} \pi / \mathrm{T}$ の間の $\omega$ に対す る $H(s)$ を得ることができる。更に，(4) 式を使えば， $Z(\omega)$ を計算することができる。(4) 式の近似が成り立つ $\alpha$ とし て, Wilcox (7)による以下の導出式を用いた。なお，適切な
(4) 式の近似を得るため, 有効な測定角周波数 $\omega$ は $\alpha$ の 10 倍とした。

$$
\alpha=2 \pi / \mathrm{T}
$$

種類にもよるが, 二次電池の特性は充放電電流や, $\mathrm{SOC}$ で良く整理される。後の〈3.2〉節で説明する電圧ステップ を加える方法 ${ }^{(6)}$ では, 電流や SOC を規定して測定するの が難しい。また，充放電電圧がニッケル水素電池のように 余り変わらないと，等分配されたSOCに対して電圧ステッ プが小さくなり過ぎ, 更に, 副反応が起こるような SOCで 定電圧充電すると, 副反応電流が恒常的に流れ続けてしま う。このような場合には, 入力を定電流ステップや電流パ ルスとし，その印加時間を規定する方が有効であると言え る。本研究では, 入力電流 $i(t)$ に対する電圧応答 $v(t)$ を測 定して, 電圧ステップ法と同じ測定原理で $Z(\omega)$ を測定し, 電圧ステップ法の結果と比較した。

\section{3. 実験装置, 各種測定法と測定結果}

$\langle\mathbf{3} \cdot \mathbf{1}\rangle$ 測定装置 入力電圧 $v(t)$, 応答電流 $i(t)$ あるいは 入力電流 $i(t)$, 応答電圧 $v(t)$ を測定するため, 図 1 のような 装置を用いた。高周波の信号を得るため, 電源の立ち上がり 速度は, 定電圧制御で使用した KEPCO BOP 20-10M と, 定 電流制御で使用した KIKUSUI PBX 20-10 共に, 図 2 のよ うに $0.5 \mathrm{msec}$ 以下を確保した。デジタル記録計を 3 台用い て, 同一充放電ステップに対する $v(t), i(t)$ を $50 \mathrm{kS} / \mathrm{sec}(1 \mathrm{sec}$ 当たり 50,000 点のデー夕を採取), $200 \mathrm{~S} / \mathrm{sec}, 0.5 \mathrm{~S} / \mathrm{sec}$ の 3 種類の間隔で一度に測定した。シャント抵抗のインダク タンスを測定し $(0.276 \mu \mathrm{H})$, 高周波域の解析への影響を考 慮した。また，電池の初期電圧に等しい定電圧を直流電源 で別途発生させ, 電池の変動電圧との差を測定した ${ }^{(0) 。 こ ~}$ れによって, 電圧の測定レンジを電圧変動に対するレンジ に拡大でき，電圧の測定精度を高めることができる。

被測定電池として市販のリチウムイオン電池（Sony

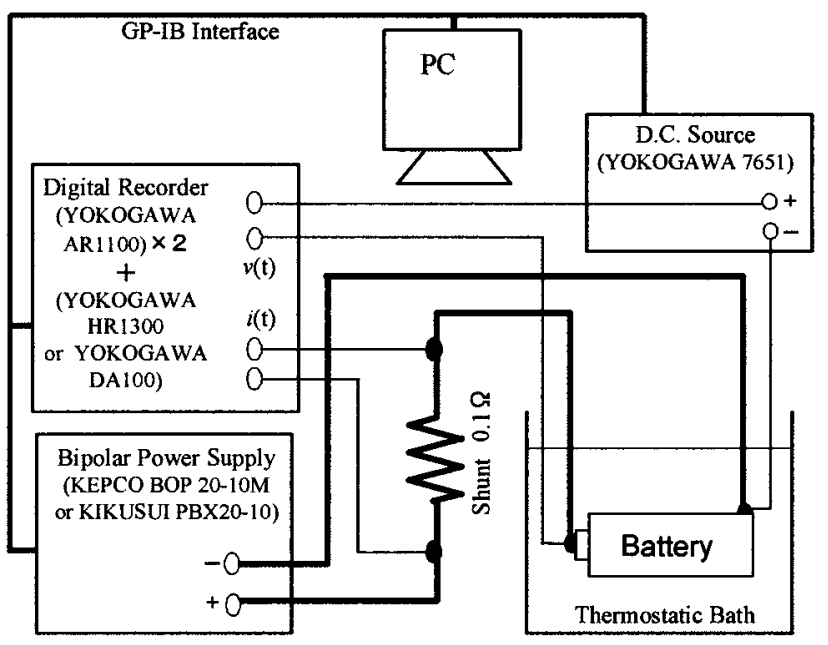

図 1 測定装置

Fig. 1. Measurement system. 

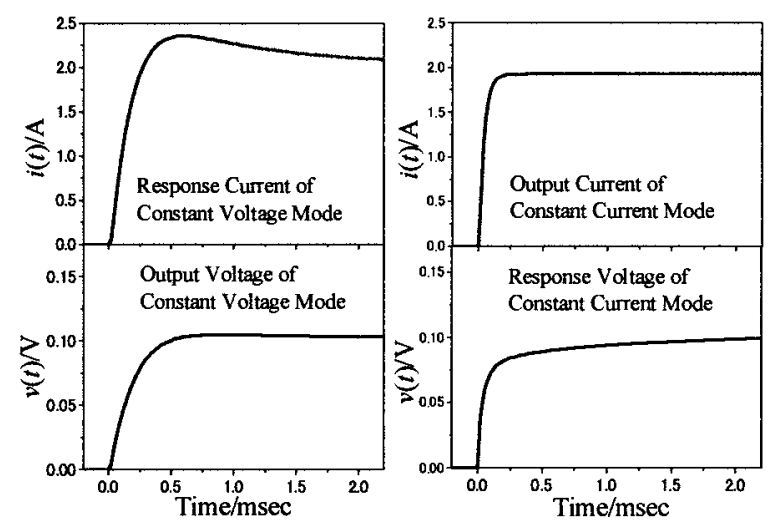

図 2 定電圧制御と定電流制御の出力応答例

Fig. 2. Examples of output voltage/current and response current/voltage of Constant Voltage/Current Mode.

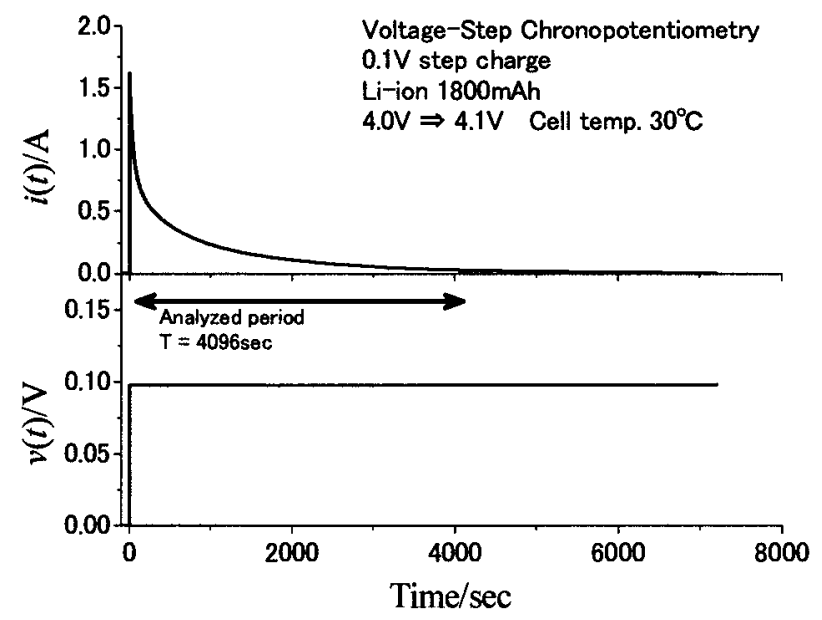

図 3 VSCA 法の測定例（リチウムイオン電池）

Fig. 3. Measurement example of VSCA (Lithium ion battery).

US186500GR，1800 mAh）と，ニッケル水素電池（Panasonic HHR-3GPS，1600 mAh）を使用した。リチウムイオ ン電池はその電池自身の正確なインピーダンスを測定対象 とするため，正極側封口にある PTC 素子を短絡させた ${ }^{(5)}$ 。 電池は絶縁ビニルシートに包み恒温水槽に沈め，電池温度 を $30^{\circ} \mathrm{C}$ に維持して測定した。

$\left\langle\mathbf{3 \cdot 2 \rangle}\right.$ 電圧ステップ法 ${ }^{(6)}$ (VSCA : Voltage-Step ChronoAmperometry）による測定図 3 に入力電圧 $v(t)$, 応答 電流 $i(t)$ の測定結果を, $4.0 \mathrm{~V}$ から $4.1 \mathrm{~V}$ にリチウムイオン 電池の電圧を上昇させた場合を例に示す。電圧ステップ幅 は充放電ともに $0.1 \mathrm{~V}$ とした。図 3 のように，0.1 Vの電圧 ステップを正に加えると，はじめ大きな充電電流が流れる が，凡そ 2 時間で電流はほぼ 0 になるため，ステップ印加 時間は 2 時間とした。

図 3 の信号に対して, サンプリング間隔を変え 5 種類の解 析期間 T $(0.164 \mathrm{sec}, 2.13 \mathrm{sec}, 41.0 \mathrm{sec}, 614 \mathrm{sec}, 4096 \mathrm{sec})$ に対し信号を解析した。結果をボード線図として示すと， 各 $\mathrm{T}$ に対応し図 4 のようなインピーダンス曲線が得られる。

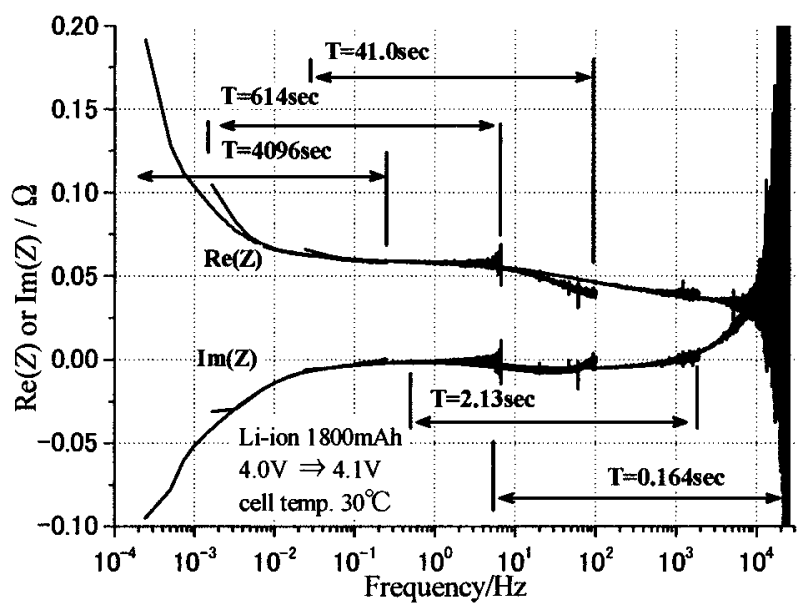

図 4 VSCA 法による $Z(\omega)$ のボード線図

Fig. 4. Bode diagram of impedance obtained by VSCA.

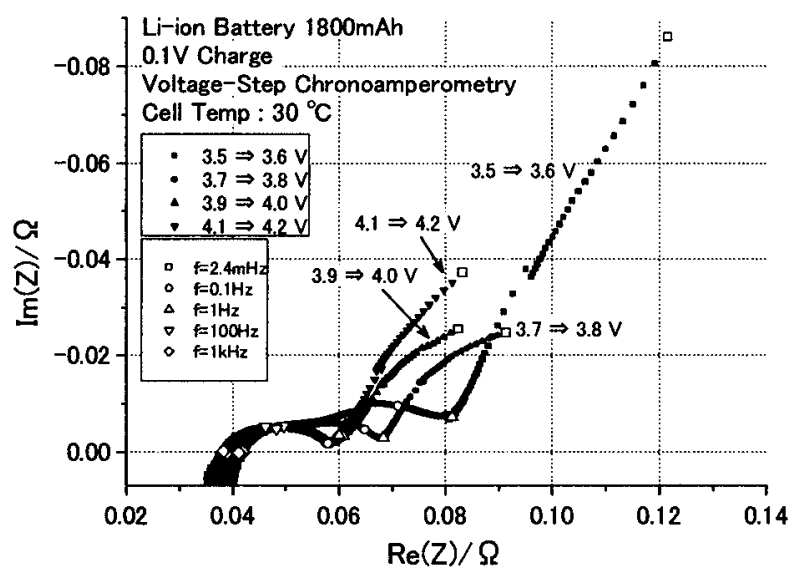

図 5 SVSCA 法による $Z(\omega)$ の Cole-Cole プロット

Fig. 5. Cole-Cole plot obtained by SVSCA from 3.5 to $4.2 \mathrm{~V}$ with $0.1 \mathrm{~V}$ step voltage.

ただし， $Z(\omega)$ の実部を $\operatorname{Re}(Z)$ ，虚部を $\operatorname{Im}(Z)$ とする。ここ で，各 $\mathrm{T}$ の低周波域には近似式 (4) に伴う誤差が生じ, 高 周波数域にはサイドバンドとノイズによると思われる誤差 が生じる ${ }^{(6)}$ 。これらを除けば低周波域から高周波域まで連 続した $Z(\omega)$ を描くことができた。

次に $3.5 \mathrm{~V}$ から $0.1 \mathrm{~V}$ の電圧ステップを与え, $4.2 \mathrm{~V}$ まで充 電状態を変えながら測定 (SVSCA：Staircase Voltage-Step Chrono-Amperometry ${ }^{\left({ }^{(6)}\right)}$ した $Z(\omega)$ の変化を図 5 に示す。 このように全体としては低電圧，すなわち SOC が低い程 $Z(\omega)$ は大きく, 充電が進み SOC が高くなるにつれ, 小さ くなる $Z(\omega)$ が高野らの結果 ${ }^{(6)}$ と同様に測定された。また, $3.9 \mathrm{~V}$ 付近からは $Z(\omega)$ の円弧の大きさの減少が鈍くなり, 低周波域での $\operatorname{Im}(Z)$ の值が大きくなった。

〈3・3〉 電流ステップ法（CSCP : Current-Step ChronoPotentiometry）による測定 $Z(\omega)$ を SOC や充放電電 流の関数として測定するため, 入力信号を電流ステップと する方法を新たに試みた。リチウムイオン電池に定電流ス テップを与え，SOCにして 0.1 の容量を充電した例を図 6 


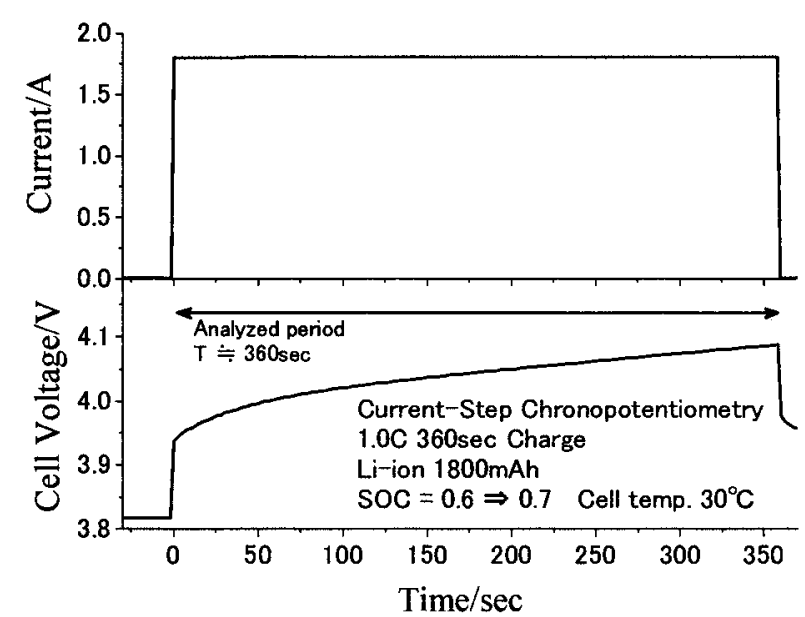

図 $6 \mathrm{CSCP}$ 法の測定例

Fig. 6. Measurement example of CSCP.

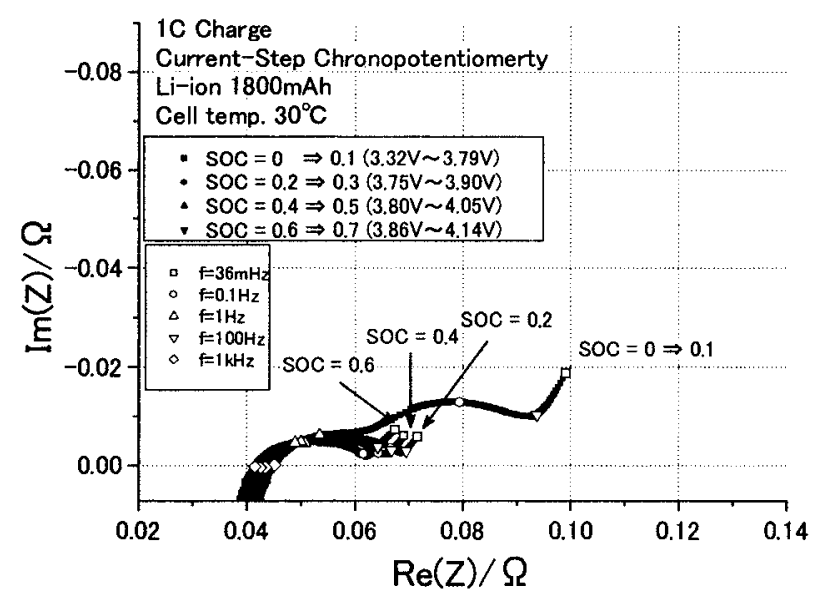

図 7 CSCP 法による $Z(\omega)$

Fig. 7. $\quad Z(\omega)$ obtained by CSCP.

に示す。電圧は最初大きく立ち上がり，その後もなだらか に上昇する。電流と電圧をVSCA 法と同様に測定し，ラプ ラス変換し，インピーダンスを求めた。

得られた $Z(\omega)$ を図 7 に示す。VSCA 法と同様にSOCが 上昇する程 $Z(\omega)$ が小さくなる。我々が測定した電池では $\mathrm{SOC}=0.1$ 程度で, 電池の無負荷電圧は $3.7 \mathrm{~V}$ 近くになり, 図 5 と同様に $Z(\omega)$ は急に小さくなる。その後は SOC が上 昇しても電圧上昇は僅かで, $Z(\omega)$ が図 5 と同様に徐々に減 少した。しかし，本 CSCP 法は電流を流しながら測定する ので, 常に SOC が変化する。つまり測定期間を長くするこ とができず，充分な低周波数域の測定ができない。よって VSCA 法で測定された低周波数域での $\operatorname{Im}(Z)$ の上昇が測定 できなかった。なお，本 CSCP 法では $0.2 \mathrm{C} ， 1 \mathrm{C} ， 3 \mathrm{C}$ の充 放電電流で測定したが, 電流が大きい程 SOC を 0.1 充放電 する時間が短くなるために低周波域が採れず，また，電流 が大きい程早く終止電圧（充電時 $4.2 \mathrm{~V}$, 放電時 $2.7 \mathrm{~V}$ ) に 達するため，広い SOC 範囲を測定できなかった。

〈3・4〉 電流パルス法（CPCP : Current-Pulse ChronoPotentiometry）による測定 SOCの变化を最小限に留

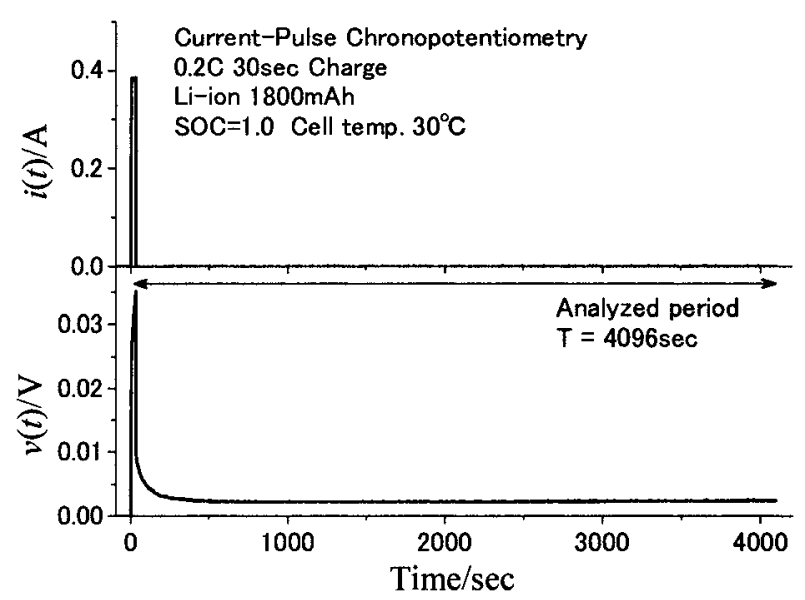

図 8 CPCP 法の測定例

Fig. 8. Measurement example of CPCP.

めるため，電流をパルス状に流し，それに対する電圧応答 を低周波域の解析に必要な長い測定期間 $\mathrm{T}$ の間で測定する 方法を次に同じリチウムイオン電池で試みた。図 8 に $0.2 \mathrm{C}$ 充電電流を 30 秒間流した例を示す。CSCP 法は図 6 のよ うに電流印加時間と解析期間 $\mathrm{T}$ が同じなのに対し, CPCP 法は図 8 のように T が充分長く採れる。CPCP 法では印加 電荷量を小さくできるので, 最終的に電圧変化は僅かであ る。しかし，印加電流とパルス印加時間の積である電荷量 が余り小さいと, 充分な電圧応答が得られず，低周波域で インピーダンスの誤差が大きくなってしまう。そこで, 最 終的な電圧変化が僅かで, 同時に充分な電圧応答が得られ る充放電電荷量の目安として，0.2C に扔いては 30 秒， $1 \mathrm{C}$

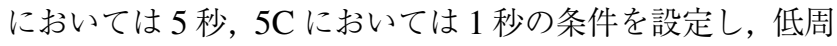
波域まで誤差が少なく, かつSOC の変化を 0.002 未満に抑 えた測定を行った。

本 $\mathrm{CPCP}$ 法では 0.2 間隔で全ての $\mathrm{SOC}$ 範囲を $0.2 \mathrm{C}, 1 \mathrm{C}$, $5 \mathrm{C}$ の充放電電流で測定した。このとき SOC や電流によっ ては終止電圧を超えるが, その時間は短いので, 電池に特に 支障はなかった。SOC = 1 と0 に対する結果を図 9(a),(b) に示す。 $Z(\omega)$ の SOC に対する変化は, CSCP や VSCA と SOC を合わせての比較はできないが, SOC が大きい程 $Z(\omega)$ は小さく, $\mathrm{SOC}=0.4$ 程度以上では低周波域の $\operatorname{Im}(Z)$ が大 きくなり, CSCP やVSCA と同様であった。一方, $Z(\omega)$ の 充放電電流による変化は $\mathrm{SOC}=1$ を含め殆どの $\mathrm{SOC}$ で, 電流の大きさ，電流の向きに因らず，図 9(a)のように殆ど 変化しなかった。しかし, $\mathrm{SOC}=0$ では例外的に図 9(b)に 示すように, 充電パルス電流が小さい程，また，充電より も放電パルス電流による $Z(\omega)$ の実部が大きくなった。

〈3.5〉 リチウムイオン電池における各種測定法の比較 図 10 には以上のラプラス変換を用いて測定した $Z(\omega)$ を まとめて比較する。また同図には，交流インピーダンス計 (Solartron 1280B) で, 周波数を掃引させながら $70 \mathrm{~mA}(\mathrm{rms})$ の微小正弦波電流を, 直流充放電電流 $=0$ の電池に印加し て測定した $Z(\omega)$ も示す。同図で, CSCP 法による $Z(\omega)$ は 


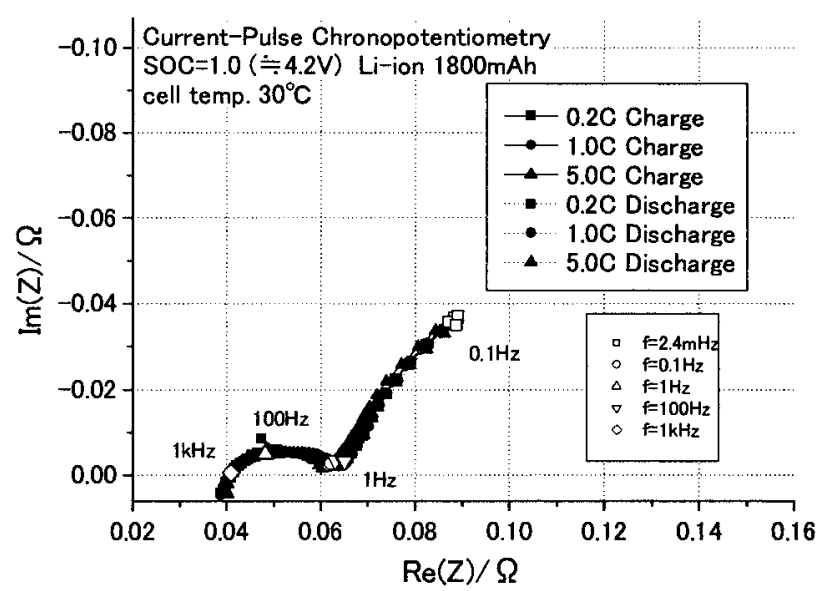

(a) $\mathrm{SOC}=1.0$

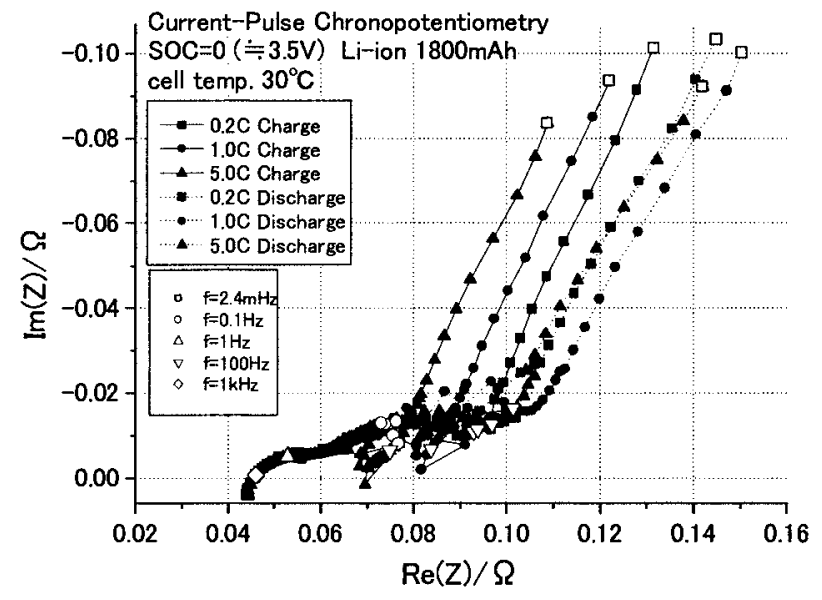

(b) $\mathrm{SOC}=0$

図 $9 \mathrm{CPCP}$ 法による $\mathrm{SOC}=1,0$ に対する $Z(\omega)$

Fig. 9. $Z(\omega)$ obtained by $\mathrm{CPCP}$ for $\mathrm{SOC}=1,0$.

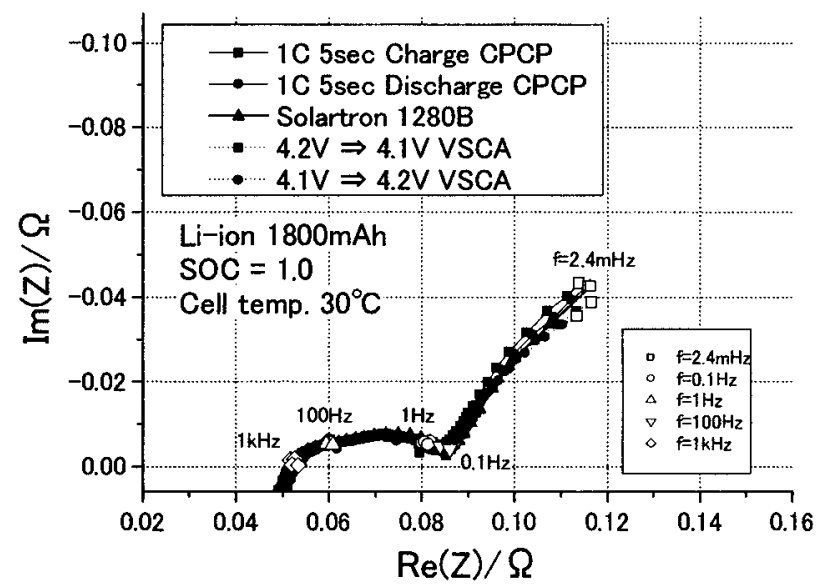

図 10 各種測定法による $Z(\omega)$ の比較

Fig. 10. Comparison of $Z(\omega)$ measured by various methods.

高周波域で CPCP 法による $Z(\omega)$ と一致したが, 低周波域の データが足りないため，省略している。測定は $\mathrm{SOC}=1.0$ のリチウムイオン電池に対し，まず CPCP 法で 5 秒間 $1 \mathrm{C}$ 充電し, 次に 5 秒間 $1 \mathrm{C}$ 放電し, 続いて交流インピーダン

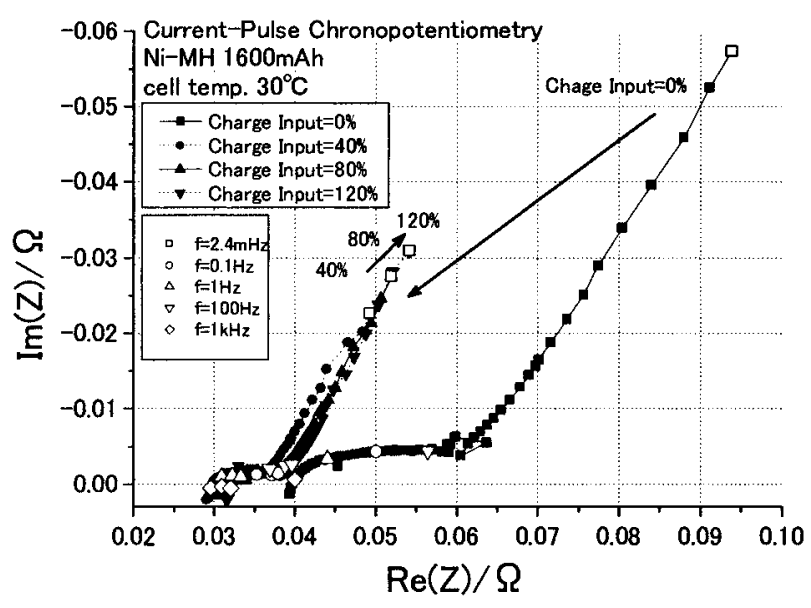

図 11 Ni-MH の CPCP 法による Z $(\omega)$

Fig. 11. $Z(\omega)$ of Ni-MH measured by CPCP.

ス計で $Z(\omega)$ を測定し，最後にVSCA 法で $0.1 \mathrm{~V}$ ステップ 放電を，次に $0.1 \mathrm{~V}$ ステップ充電を行った。低周波域で多 少の差が見られるものの，どの方法による $Z(\omega)$ も良く一 致している。なお，このような比較測定はSOC と開回路

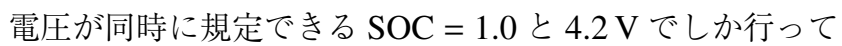
いないが，これらが凡そ一致する範囲では図 5, 図 7, 図 9 で示したように $Z(\omega)$ はほぼ等しい軌跡を描いている。

何れの方法でも同じ $Z(\omega)$ が得られることから, 測定法の 操作性を考えれば, CPCP 法が最も優れていると思われる。 すなわち，(1)プラス変換による特徵の一つである広い周 波数域でインピーダンスを一度に計れること, (2)SOCや， 電流の大きさと充放電電流の向きを規定できること, (3)測 定中の SOC が殆ど変わらないこと, (4)電荷量を小さく抑え て電流印加パルス時間を適当に選択すれば，低周波域でも 少ない誤差で測定できること，などが優位点として挙げら れる。

〈3.6〉 ニッケル水素電池の測定 ニッケル水素電池の $Z(\omega)$ を CSCP 法と CPCP 法で測定した。両方法共にリチ ウムイオン電池と同じように計れば, $Z(\omega)$ が得られること が分かった。つまり, 電荷量を小さく抑えて，5C の充放電 電流までパルス印加時間を適当に選べば，ごく浅い充電状 態を除き，電流の大きさと向きに因らず， $2.4 \mathrm{mHz}$ まで低 周波域の $Z(\omega)$ が測定できることが分かった。

図 11 に, $1 \mathrm{C}$ 電流で 5 秒間充電した $\mathrm{CPCP}$ 法による $Z(\omega)$ を, 電池の充電入力量 (Charge Input) (2) をパラメータに示 す。充電入力量が小さい場合（リチウムイオン電池の小さ いSOC に対応), $Z(\omega)$ が他の充電入力量の場合に比べて極 めて大きい。しかし，その後は充電入力量が増えるに従い $Z(\omega)$ は急に下がり, 副反応が起こる充電入力量当たりから $Z(\omega)$ は少しずつ大きくなった。

\section{4. 等価回路の作成と過電圧抵抗との比較}

$\langle\mathbf{4} \cdot \mathbf{1}\rangle$ 等価回路の作成 測定された $Z(\omega)$ は電池内の 反応系を良く反映できると考えられる図 12 のような等価 


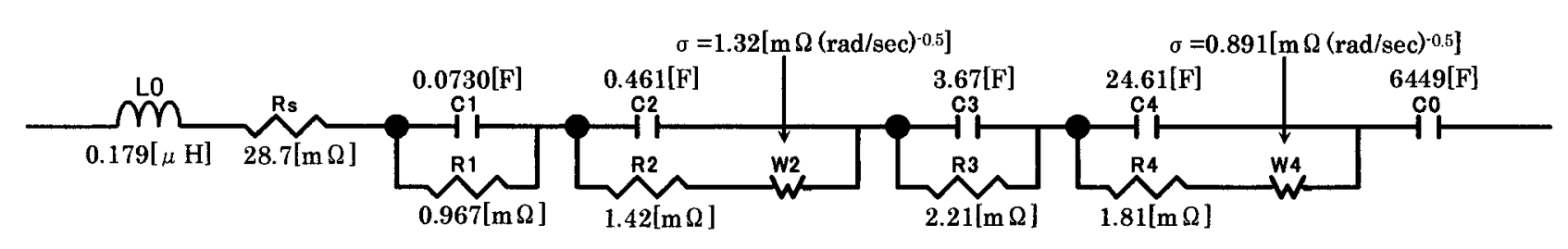

(a) Ni-MH (Charge Input $=40 \%$ )

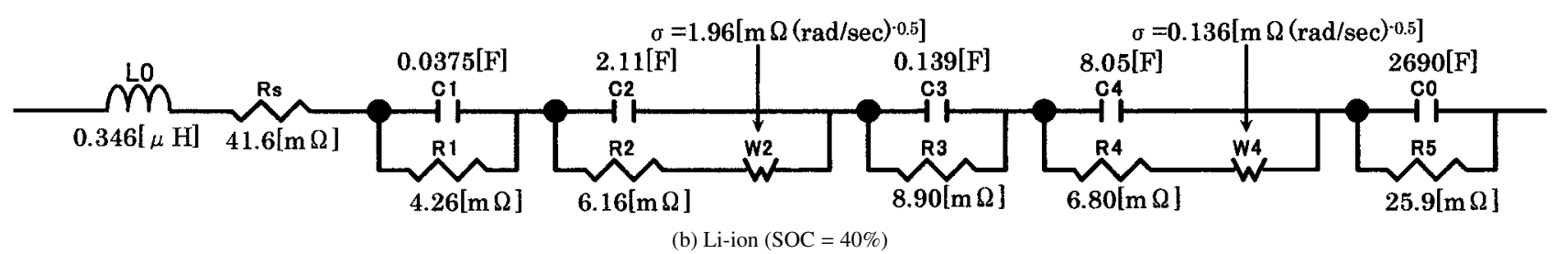

図 12 電池の等価回路

Fig. 12. Equipment circuit of battery.

回路で近似した。ここで，それぞれの回路素子に対応する 電池の構成素子は次のように考えられる ${ }^{(8)}$ 。

L0 : 電池のスパイラル構造などに起因するインダクタ ンス

Rs：電解質抵抗や活物質, 集電体などの電子抵抗を合 わせた直列抵抗

$\mathrm{C} 1, \mathrm{C} 3, \mathrm{R} 1, \mathrm{R} 3$ : 正負極界面に生じる保護皮膜など の半導体層の容量と抵抗

C2, C4：正負極界面の反応に伴う電気二重層容量

$\mathrm{R} 2$ と $\mathrm{W} 2, \mathrm{R} 4$ と $\mathrm{W} 4$ :

正負極界面の反応に伴うファラデーインピーダンス で，R2，R4：電荷移動抵抗，W2，W4：拡散に関連

する Warburg インピーダンス $Z_{W}$

$\mathrm{C} 0$ : 電池の容量

図 11 のような $Z(\omega)$ の Cole-Cole プロットの半円部は $\mathrm{R}$ と C の並列回路で記述される。我々が測定した二次電池で は，正負極の $\mathrm{RC}$ 並列回路の時定数が異なるため，半円の 描かれる周波数が異なり, 円弧が横に伸びる。電池の SOC や充電入力量が変わると円弧の大きさや形状が変わるのは, 電池の SOC や充電入力量の変化に伴い, 以上の 4 種類の抵 抗と容量のいずれか，もしくは複数が変化するためである。 個々の回路素子の帰属を決めるためには，実際に正負極の 各素子を個別に変えて測定する必要がある。しかし，ここ では帰属は決めず，図 12(a)，(b)のような等価回路のみを 検討した。

電極反応が拡散律速となる場合, Cole-Cole プロットの 低周波域に表れる傾き $45^{\circ}$ の直線部は次式のような $Z_{W}$ で 記述される(4)。

$$
Z_{W}=\sigma \omega^{-1 / 2}-j \sigma \omega^{-1 / 2}
$$

ここで， $\sigma$ は酸化体や還元体の濃度や拡散係数などで決ま る值を表す。我々が測定した電池の Cole-Cole プロットで は，低周波域における傾きが $45^{\circ}$ を超えている。これは $Z_{W}$ 以外に電池の容量成分 $\mathrm{C} 0$ を加えることにより表すことが できた。特にリチウムイオン電池では, 低周波域の $Z(\omega)$ に
合わせるため，低周波域で大きい時定数を持つ図 12(b) の ような $\mathrm{C} 0$ と $\mathrm{R} 5$ の RC 並列回路を加えることにより, 実測 $Z(\omega)$ に合わせることができた。

$1 \mathrm{C}$ 電流で 5 秒間充放電させる CPCP 法により測定され た $Z(\omega)$ を, 図 12 の等価回路で $\omega$ を変えて最小二乗近似 したところ, ニッケル水素電池, リチウムイオン電池共に, 全ての充電入力量, SOC に対し等価回路による $Z(\omega)$ と実 測值 $Z(\omega)$ との平均二乗誤差は $1 \%$ 未満であった。図 12 に 充電入力量 $=40 \%, S O C=0.4$ に対して得られた回路素子 の值を一例として示した。

$\langle\mathbf{4} \cdot \mathbf{2}\rangle$ 発熱挙動解析に用いた過電圧抵抗との比較 以 上のように等価回路で近似した $Z(\omega)$ の抵抗成分を, 発熱挙 動解析で用いた充放電特性から求めた過電圧抵抗(2)(3) と比 較してみる。図 13(a)にリチウムイオン電池の放電時の比 較を, 図 13(b) にはニッケル水素電池の充電時の比較を示 す。ここで, R(OCV-CV) は開回路電圧 $(\mathrm{OCV})$ と電池電圧 (CV) の差をその時の充放電電流で割った抵抗を, R(V-I) は各充放電電流での電池電圧の推移を V-I 特性に整理し, その傾きから求めた抵抗を, そして, R(60 sec) は充放電中 に60 秒間の休止を挟んだ電圧変化をその時の充放電電流 で割った抵抗を表す。

図 13 には $Z(\omega)$ の抵抗成分として, 等価回路で $Z_{W}$ が表れ る低周波域を除いた抵抗 $(\mathrm{Rs}+\mathrm{R} 1+\mathrm{R} 2+\mathrm{R} 3+\mathrm{R} 4)(Z(\omega)$ の円弧の右端に相当, 周波数は約 $1 \mathrm{~Hz})$ と, 最低測定周波 数 $2.4 \mathrm{mHz}$ に扔ける $Z_{W}$ を含めた $\operatorname{Re}(Z)$ もプロットした。 $Z(\omega)$ のいずれの抵抗成分も $\mathrm{R}(\mathrm{V}-\mathrm{I})$ などの過電圧抵抗より 小さくなった。しかし， $Z_{W}$ が(6) 式で近似されることから, 更に低い周波数まで $Z_{W}$ を測定すれば, $\operatorname{Re}(Z)$ が過電圧抵 抗に近づくと予想される。 $\mathrm{R}(60 \mathrm{sec})$ が $\operatorname{Re}(Z)$ に近い值を示 すのは, $\mathrm{R}(60 \mathrm{sec})$ が充放電中に 60 秒の休止を挟んで得ら れる電圧変動の時間変化に対応し, $\operatorname{Re}(Z)$ も早い時間に対 応する抵抗を表すためと考えられる。一方, 発熱挙動を最 も良く記述した $\mathrm{R}(\mathrm{V}-\mathrm{I})$ は実際の発熱が起こる電流推移に近 い状態で測定されたので, 電池の発熱が起こる時間変化と 比較的良く一致していたためと考えられる。 


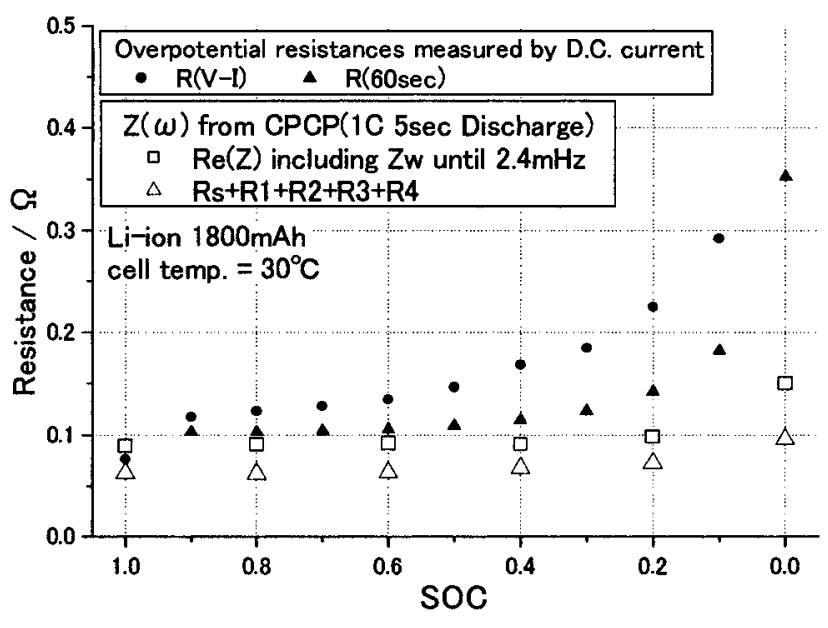

(a) Li-ion during discharge

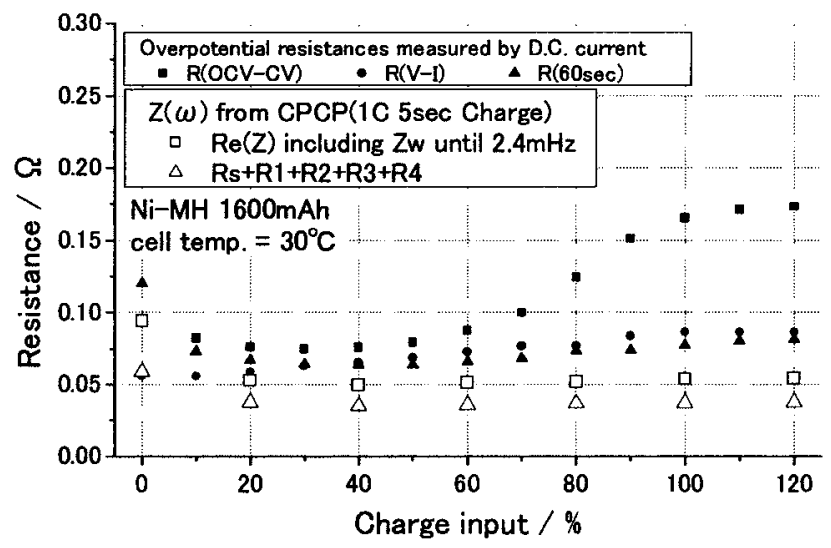

(b) Ni-MH during charge

図 13 過電圧抵抗との比較

Fig. 13. Comparision for overpotential resistance.

以上のように電池の等価回路がある程度推定できるよう になったので，後は電池起電力が電池の状態量（SOC や温 度など）の関数として推定できるようになれば，等価回路 の発熱量を計算することができよう。今後，このような考 えを基に過電圧抵抗の推定法の研究を更に続けたい。

\section{5. まとめ}

リチウムイオン電池とニッケル水素電池における発熱挙 動を解析した際，発熱因子として重要な過電圧抵抗の測定 で，交流インピーダンス計による電池インピーダンスは充 放電電流で測定した過電圧抵抗と一致しなかった。そこで, 高野らの電圧ステップを印加するラプラス変換によるイン ピーダンス測定法を発展させ，CSCP 法や電流の大きさや 向きが変えられる CPCP 法を考案し，実際にリチウムイオ ン電池やニッケル水素電池の充放電インピーダンスを測定 した。その結果，三つの方法によるインピーダンスは交流 インピーダンス計も含め良く一致し，CSCP 法は低周波域 のインピーダンスの測定に限界があることが分かった。ま た, 充電初期を除いて殆どの充電状態や充電入力量で, 充放 電の向きや電流の大きさに因らず CPCP 法によるインピー ダンスは殆ど変わらないことを得た。また，充分に低周波
域まで測定すれば，Warburg インピーダンスを含めたイン ピーダンスは過電圧抵抗に近づくが，電池の熱挙動を良く 説明した過電圧抵抗よりまだ小さいことが分かった。今後, 電池起電力の変化を考慮した等価回路を検討し, 両者の差を 詰める研究を続けたい。VSCA 法によるインピーダンス測 定に際し，(独）産業技術総合研究所の高野清南氏と齋藤喜 康氏に多大なご指導を頂いた。ここに感謝の意を表す。ま た本研究の一部は文部科学省 21 世紀 COE プログラム「イ ンテリジェントヒューマンセンシング」の援助により行わ れた。

(平成 17 年 2 月 22 日受付, 平成 17 年 5 月 23 日再受付)

$$
\text { 文献 }
$$

（1） 辰巳国昭：「ユビキタス情報時代における二次電池技術」, IEEE J., Vol.125, No.1, pp.34-37 (2005)

(2) M. Nakayama, K. Fukuda, T. Araki, and K. Onda: "Thermal Behavior of Nickel-Metal Hydryde Battery during Rapid Charge and Discharge Cycles", IEEE Trans. PE, Vol.125, No.2, pp.213-220 (2005-2) (in Japanese) 中山正人・福田健一・荒木拓人・恩田和夫 :「ニッケル水素電池の急 速充放電時の発熱挙動」, 電学論 B, 125, 2, pp.213-220 (2005-2)

3 T. Ohshima, M. Nakayama, K. Fukuda, T. Araki, and K. Onda: "Thermal Behavior of Small Lithium-Ion Secondary Battery during Rapid Charge and Discharge Cycles", IEEE Trans. PE, Vol.124, No.12, pp.1521-1527 (200412) (in Japanese)

大島孝昌・中山正人 ·福田健一・荒木拓人 ·恩田和夫 :「小型リチウムイ オン電池の急速充放電時の発熱挙動」, 電学論 B, 124, 12, pp.1521-1527 (2004-12)

（4）板垣昌幸:「電気化学インピーダンスでわかる固／液界面の物性」,材 料科学, Vol.39, No.2, pp.50-53 (2002-4)

(5) K. Takano, K. Nozaki, Y. Saito, A. Negishi, K. Kato, and Y. Yamaguchi: "Simulation study of electrical dynamic characteristics of lithium-ion battery", J. Power Sources, Vol.90, pp.214-223 (2000)

(6) K. Takano, K. Nozaki, Y. Saito, K. Kato, and A. Negishi: "Impedance Spectroscopy by Voltage-Step Chronoamperometry Using the Laplace Transform Method in a lithium-ion battery", J. Electrochemical Society, Vol.147, No.3, pp.922-929 (2000)

(7) D.J. Wilcox: "Numerical Laplace Transformation and Inversion", Int. J. Elect. Enging Educ., Vol.15, pp.247-265 (1978)

(8) K. Takano, K. Nozaki, Y. Saito, and Y. Yamaguchi: "Analysis of Electrical Characteristics of Batteries by Laplace Transform", National Convention Record IEE Japan, 7-315, pp.315-316 (1998) (in Japanese) 高野清南・野崎 健・斎藤善康・山口由雄: 「電池電気特性のラプラ ス変換による解析法」, 平成 6 年電気学会全国大会, 7-315, 第 7 分冊, pp.315-316 (1998)

中 山 正人 (学生員) 1980 年 9 月 23 日生。 2003 年 3 月豊橋

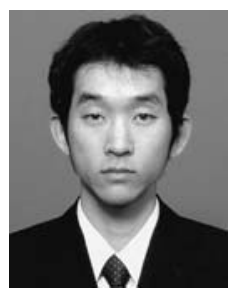
技術科学大学工学部電気電子工学課程卒業。2005 年 3 月同大学大学院工学研究科電気電子工学専攻 修士課程修了。主として，二次電池に関する研究 に従事。

福 田 健 - (学生員) 1981 年 5 月 30 日生。 2004 年 3 月豊

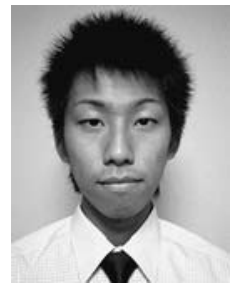
橋技術科学大学工学部電気電子工学課程卒業。現 在同大学大学院工学研究科電気電子工学専攻修士 課程に在学中。主として，二次電池に関する研究 に従事。 


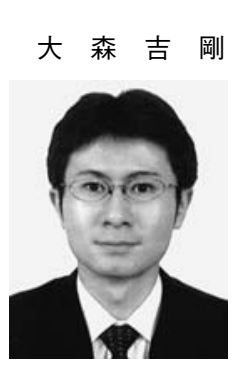

荒 木 拓人 (正員) 1975 年 5 月 2 日生。 2003 年 3 月京都大 台電波工業高等専門学校専攻科電子システム工学 専攻修了。現在同大学大学院工学研究科電気電子 工学専攻修士課程に在学中。主として, 二次電池 に関する研究に従事。

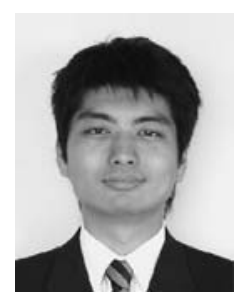
学大学院工学研究科博士課程修了。2004 年 1 月 豊橋技術科学大学助手 (電気電子工学系)。主と して, 燃料電池, 水電解, 二次電池, 放電脱硝に 関する研究に従事。電気化学会, 機械学会, 伝熱 学会会員。工学博士。

若 原 健 二 (学生員) 1982 年 10 月 16 日生。 2004 年 3 月豊 橋技術科学大学工学部電気電子工学課程卒業。現 在同大学大学院工学研究科電気電子工学専攻修士 課程に在学中。主として, 二次電池に関する研究 に従事。
恩田 和夫

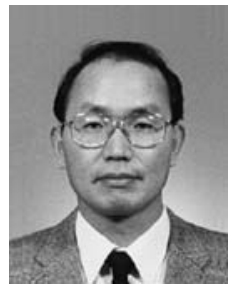

（正員） 1941 年 6 月 20 日生。1966 年 3 月東京 工業大学大学院理工学研究科修士課程修了。同年 10 月電子技術総合研究所入所。1 1995 年 9 月豊橋 技術科学大学教授 (電気電子工学系)。主として, 燃料電池, 二次電池などの研究に従事。電気化学 会, 応用物理学会, エネルギー・資源学会会員。 工学博士。 